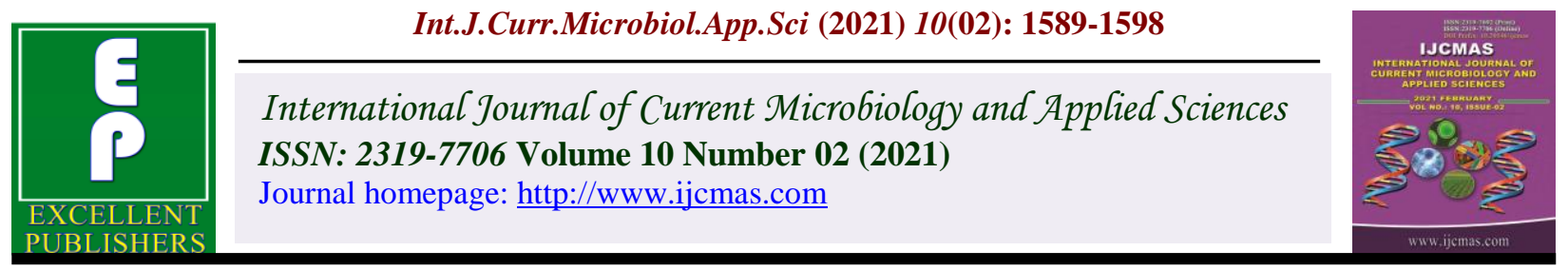

Original Research Article

https://doi.org/10.20546/ijcmas.2021.1002.189

\title{
Quality Attributes of Curcuma longa in response to Populus deltoides Tree Spacings and Nutrient Sources
}

\author{
Umakanta Dash*, Bhupender Gupta, Jyotiraditya Das and Shilpa \\ Department of Silviculture and Agroforestry, Dr. YS Parmar University of Horticulture and \\ Forestry, Nauni, Solan-173230 \\ *Corresponding author
}

Keywords

Populus deltoides, Curcuma longa, Quality, Tree spacing, Nutrient sources, Curcumin

Article Info

Accepted:

15 January 2021

Available Online:

10 February 2021
A field experiment was carried out at an experimental field of the Department of Silviculture and Agroforestry, Dr. Y S Parmar University of Horticulture and Forestry, Nauni, Solan (HP) during the years 2019-2020, to determine the effect of tree spacings and nutrient sources on quality attributes of $C$. longa. The experiment was laid out in Factorial RBD, consisting of three main plot treatments $\left(P\right.$. deltoides tree spacings i.e. $\mathrm{S}_{1}$, $\mathrm{S}_{2}, \mathrm{~S}_{0}$ ) and eight sub-plot treatments (nutrient sources i.e. $\mathrm{T}_{1}$ to $\mathrm{T}_{8}$ ) replicated thrice. Application of $\mathrm{T}_{3}(75 \% \mathrm{RDNF}+25 \% \mathrm{RDN}$ through FYM) resulted in maximum quality attributes (curcumin, oleoresin, essential oil, crude fibre content) of $C$. longa. Under tree spacings, maximum curcumin, oleoresin and essential oil content were registered under wider spacing of $P$. deltoides $\left(\mathrm{S}_{1}\right)$ whereas crude fibre content was found maximum in open field $\left(\mathrm{S}_{0}\right)$.

\section{Introduction}

Turmeric (Curcuma longa L.) also called as "Indian saffron" is an ancient, most valuable and sacred spice crop of India where large amount of Turmeric is produced, consumed and exported. It belongs to family Zingiberaceae and is native to the Indian subcontinent and southeast Asia and grows well in temperature between $20^{\circ}-30^{\circ} \mathrm{C}$ (Anonymous, 2017). It is mainly propagated through rhizome with a seed rate of 20-25 q/ha sown during the month of April-May in midhill regions of the country (Anonymous, 2014). Indian Turmeric is considered best in the world market because of its high curcumin content i.e. $3.14 \%$ by weight (Hembram, 2014). Curcumin the yellow colour bioactive pigment present in the rhizome was identified in 1815 which has antioxidant, antiinflammatory, anticancer, antibacterial, antirheumatic, antidiabetic and antiviral 
properties is gaining importance with ban on artificial colours in food industry. Demand growth rate of Turmeric is around $10 \%$ pointing to future prospects of Turmeric cultivation in the country (Chanchan et al., 2017). The utilization of Turmeric by humankind presumably started for its dye (curcumin) which has a rich history of usage not only truncated to colouring foods but also now in the various other textile and pharmaceutical industries. Therefore, quality or bio-chemical traits of Turmeric have a linear relationship with its marketability. $C$. longa with less crude fibre, high essential oil, curcumin, oleoresin is considered as superior which mainly depends upon the cultivar variety, shade levels and nutrient sources. A certain degree of shade has a vital role in influencing growth, yield and quality of Turmeric (Padmapriya et al., 2007 and Ranawat et al., 2018). Therefore, in the present study Turmeric was grown under Poplar with the application of different nutrient sources to evaluate the contribution of tree spacings and nutrient sources in enhancing the quality of Turmeric.

\section{Materials and Methods}

The present study was conducted at an experimental field of the Department of Silviculture and Agroforestry, Dr. Y S Parmar University of Horticulture and Forestry, Nauni, Solan (HP) during the years 20192020. The experiment consisted of two structural components viz. $P$. deltoides as woody perennial and $C$. longa as intercrop in agrisilviculture agroforestry system. It was laid out using Factorial RBD with 24 treatment combinations replicated thrice. Plots of $5 \mathrm{~m} \times 4 \mathrm{~m}, 3 \mathrm{~m} \times 4 \mathrm{~m}$ and $3 \mathrm{~m} \times 1 \mathrm{~m}$ were prepared in between $P$. deltoides tree spacing of $6 \mathrm{~m} \times 4 \mathrm{~m}$ and $4 \mathrm{~m} \times 4 \mathrm{~m}$ and, in open condition, respectively, to accommodate all treatments as per treatment details mentioned below:

\section{Methods used for estimating quality parameters of rhizomes of $C$. longa}

\section{Curcumin content}

As per the procedure outlined by ASTA, $0.1 \mathrm{~g}$ of powdered Turmeric was weighed and put into a round bottomed flask. Then $30 \mathrm{ml}$ of Ethanol (solvent) was added and the round bottom flask was connected with a refluxing condenser for two and half hours.

After condensation the apparatus was allowed to cool down. The residue was filtered into a volumetric flask and the volume was made $100 \mathrm{ml}$ by adding Ethanol. Further, $2 \mathrm{ml}$ of it was pipette out and volume was made $25 \mathrm{ml}$ using Ethanol. In the end absorbance was measured using spectro-20 at a wavelength of $425 \mathrm{~nm}$ using alcohol as blank.

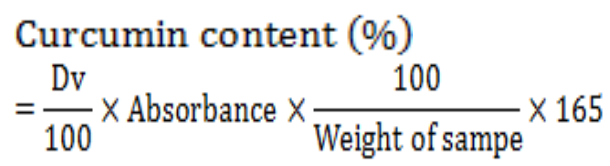

Where, Dv $=$ Dilution Volume

\section{Oleoresin content}

Ten grams of dried, powdered sample of Turmeric was weighed and put in the fitted glass column on a stand containing cotton plug. Further, the column was filled to the brim with Acetone and kept overnight. In the next morning, an empty beaker $\left(\mathrm{W}_{1}\right)$ was weighed and the extracts were collected from the column in $\mathrm{W}_{1}$. Then the beaker was kept in hot boiling water bath for vaporisation of acetone contents. After evaporation, the beaker $\left(\mathrm{W}_{2}\right)$ was weighed again and oleoresin contents were calculated by using the formula below:

$$
\begin{aligned}
& \text { Oleoresin content }(\%) \\
& =\frac{w_{2}-w_{1}}{\text { Weight of sample }} \times 100
\end{aligned}
$$


Where, $\mathrm{W}_{2}=$ weight of beaker + extract, $\mathrm{W}_{1}=$ weight of empty beaker

\section{Essential oil}

Ten grams of dried meshed fine powdered sample of Turmeric was weighed and put in a Clevenger apparatus followed by adding of $250 \mathrm{ml}$ of water. Then the apparatus was set for distillation on heater till the contents boil (at least for 45-60 minutes).

After boiling, exact quantity of essential oil collected was measured in the graduated pipette attached with the apparatus to calculate the essential oil content in rhizome by the following formula:

Essential oil (\%)

$=\frac{\text { Amount of oil collected }}{\text { Weight of sample }} \times 100$

\section{Crude fibre}

Residue obtained after extraction of oleoresin was used for estimation of crude fibre. Two grams of the residue was taken and digested for 30 minutes with $200 \mathrm{ml}$ of $1.25 \%$ Sulphuric acid, filtered with boiling water and then digested in $200 \mathrm{ml}$ of $1.25 \%$ Sodium hydroxide for 30 minutes. The digested material was filtered with $25 \mathrm{ml}$ of $1.25 \%$ Sulphuric acid, $30 \mathrm{ml}$ of water, $15 \mathrm{ml}$ of alcohol and put in an empty weighed crucible $\left(\mathrm{W}_{1}\right)$. The crucible was put in an oven for oven drying at $130 \pm 2^{0} \mathrm{C}$ for two hours and weighed $\left(\mathrm{W}_{2}\right)$ followed by ignition for 30 minutes at $600 \pm 15^{\circ} \mathrm{C}$ in a muffle furnace and weighed accurately $\left(\mathrm{W}_{3}\right)$. The crude fibre was calculated as:

Crude fibre $(\%)$

Loss in weight

on ignition $\left(\mathrm{w}_{2}-\mathrm{w}_{1}\right)-\left(\mathrm{w}_{3}-\mathrm{w}_{1}\right)$

=---------------------------------------- $\times 100$

Weight of sample
Where, $\mathrm{W}_{1}=$ Weight of empty crucible

$\mathrm{W}_{2}=$ Oven dried weight of crucible + extract

$\mathrm{W}_{3}=$ Final weight of crucible + extract after ignition

\section{Results and Discussion}

It was observed that $P$. deltoides tree spacing and nutrient sources had significantly influenced the quality attributes of $C$. longa whereas the combined effect of tree spacing and nutrient sources was found insignificant (Fig. 1-5).

\section{Curcumin content}

The main active principle of Turmeric rhizome is curcumin, a hydrophobic polyphenol belonging to the group of curcuminoids, which are natural phenols responsible for yellow colour of Turmeric (Choudhry, 2019). It is believed that curcumin is produced in leaves and is then translocated to rhizome as stated by Li et al., (2011). Under tree spacings, highest curcumin content (3.48 $\%$ ) was exhibited under $\mathrm{S}_{1}$ which was at par with $\mathrm{S}_{2}(3.40 \%)$ and minimum $(2.92 \%)$ under $\mathrm{S}_{0}$. Maximum curcumin content under tree canopy indicated the positive effect of shade on curcumin synthesis, translocation, and assimilation in the rhizome (Kumar et al., 2018). However curcumin content decreased in open may be due to increase in weight and volume of fresh rhizome without proper corresponding synthesis of curcumin as reported by Rao et al., (1975). Hossain et al., (2009) also recorded maximum curcumin content under lower light intensity. Curcumin is an important quality trait of Turmeric, as economic value of Turmeric depends upon it (Aarthi et al., 2018).

Among nutrient sources, in treatment $\mathrm{T}_{3}$ curcumin content was maximum (3.94 \%) 
which was at par with $\mathrm{T}_{4}(3.88 \%)$ and minimum $(2.31 \%)$ in $\mathrm{T}_{1}$ which is in corroboration with results of Padmapriya et al., (2004) who purported maximum curcumin content with application of $75 \%$ inorganic Nitrogen + FYM + Azospirillum and Verma et al., (2012) accounted $3.18 \%$ of curcumin content by application of $75 \%$ RDF of NPK + 10 t FYM ha-1 + Azotobactor. Similarly, Shah and Muthuswamy (1981) reported an increasing trend of curcumin content with increase in levels of Nitrogen upto $120 \mathrm{~kg} \mathrm{ha}^{-1}$ (Table 1).

\section{Oleoresin content}

Oleoresins are yellow-dark reddish brown oily fluids obtained when a spice is extracted with a hydrocarbon solvent. Under tree spacings, in treatment $\mathrm{S}_{1}$ oleoresin content was highest $(11.44 \%)$ which was at par with $\mathrm{S}_{2}(11.37 \%)$ and minimum $(9.06 \%)$ under $\mathrm{S}_{0}$. Correspondingly, Kittur et al., (2015) also purported higher oleoresin content of Turmeric at widest spacing of Bamboo in comparison to other three spacings and treeless control which substantiates complementary to our results.

Among nutrient sources, $\mathrm{T}_{3}$ registered maximum oleoresin content $(12.80 \%)$ which was statistically at par with $\mathrm{T}_{4}(12.60 \%)$ and $\mathrm{T}_{5}(12.10 \%)$ while $\mathrm{T}_{6}(11.09 \%)$ was at par with $\mathrm{T}_{7}(10.30 \%), \mathrm{T}_{8}(9.98 \%)$ and minimum $(6.96 \%)$ in $\mathrm{T}_{1}$. The results of present study connotes similar to Chandrasekhar and Hore (2019) who elucidated that oleoresin content decreased with the decreasing level of inorganic NPK i.e. $6.86 \%$ to $6.59 \%$ with reduction of NPK from 100 - $50 \%$ (Table 2).

\section{Essential oil content}

Under tree spacings, $\mathrm{S}_{1}$ exhibited highest essential oil (5.26 \%) which was at par with $\mathrm{S}_{2}$ $(5.17 \%)$ and lowest $(4.27 \%)$ under $\mathrm{S}_{0}$.
Similar effect of tree canopy on maximum essential oil recovery was reported by Thakur et al., (2009) who observed maximum oil recovery from Ocimum sanctum grown under Morus alba in comparison to treeless control. This was presumably due to enhanced soil properties under agroforestry system and positive effects of shade on biosynthesis of secondary metabolites as reported by Suvera et al., (2015). Further, Sarangi et al., (2007) elucidated that Turmeric grown under the shade of Cinnamomum camphora, Cunninghamia lanceolata and Mesua ferrea recorded highest curcumin, essential oil and oleoresin contents in rhizomes.

Among nutrient sources, $\mathrm{T}_{3}$ registered maximum essential oil $(6.17 \%)$ which was statistically at par with $\mathrm{T}_{4}(6.06)$ and minimum $(2.90 \%)$ in $\mathrm{T}_{1}$. Montemurro (2009) reported that the partial substitution of inorganic fertilizer with organic manures enhance the quality traits of field crops in comparison with sole use of inorganic fertilizer (Table 3).

\section{Crude fibre content}

Crude fibre also known as weende cellulose is the insoluble remnant of an acid-alkali hydrolysis. It is the indication of the level of non digestible carbohydrate and lignin. Under tree spacings, highest crude fibre content (5.12 $\%)$ was recorded under treatment $\mathrm{S}_{0}$ and minimum $(4.25 \%)$ under $\mathrm{S}_{2}$.

Similarly, Jaswal et al., (1993) purported maximum crude fibre content in sole cropping and observed a decreasing trend with decrease in $P$. deltoides tree spacing which corroborates our findings.

Among nutrient sources, $\mathrm{T}_{3}$ registered maximum crude fibre content $(5.91 \%)$ which was at par with $\mathrm{T}_{4}(5.66 \%)$ and minimum (3.15\%) in $\mathrm{T}_{1}$ (Table 4-6). 
Table.4 Effect of P. deltoides trees spacing (S) and nutrient sources (T) on oleoresin content (\%) in C. longa

\begin{tabular}{|c|c|c|c|c|}
\hline \multirow[t]{2}{*}{ NUTRIENT SOURCES } & \multicolumn{2}{|c|}{$\begin{array}{c}\text { P. deltoides tree } \\
\text { spacing }\end{array}$} & \multirow[b]{2}{*}{$\begin{array}{c}\mathbf{S}_{0} \\
(\text { Open })\end{array}$} & \multirow[b]{2}{*}{ Mean } \\
\hline & $\begin{array}{c}S_{1} \\
(6 \times 4 \mathrm{~m})\end{array}$ & $\begin{array}{c}S_{2} \\
(4 \times 4 \mathrm{~m})\end{array}$ & & \\
\hline$T_{1}:$ Control & 7.68 & 7.31 & 5.89 & 6.96 \\
\hline $\mathrm{T}_{2}: 100 \%$ RDNF & 10.07 & 9.54 & 7.86 & 9.16 \\
\hline $\mathrm{T}_{3}: 75 \%$ RDNF + $25 \%$ RDN through FYM & 13.86 & 13.65 & 10.89 & 12.80 \\
\hline $\mathrm{T}_{4}: 50 \%$ RDNF + $50 \%$ RDN through FYM & 13.70 & 13.47 & 10.64 & 12.60 \\
\hline $\mathrm{T}_{5}: 25 \%$ RDNF + $75 \%$ RDN through FYM & 13.30 & 12.90 & 10.09 & 12.10 \\
\hline $\mathrm{T}_{6}: 100 \%$ RDN through FYM & 12.31 & 11.85 & 9.10 & 11.09 \\
\hline $\mathrm{T}_{7}: 100 \% \mathrm{RDN}$ through VC & 9.31 & 12.03 & 9.57 & 10.30 \\
\hline $\mathrm{T}_{8}:$ Jeevamrut $(10 \%)$ & 11.27 & 10.24 & 8.44 & 9.98 \\
\hline Mean & 11.44 & 11.37 & 9.06 & \\
\hline $\begin{array}{ll}\mathrm{CD}_{0.05} & \\
\mathrm{~S} & \mathbf{0 . 7 6} \\
\mathrm{T} & \mathbf{1 . 2 4} \\
\mathrm{S} \times \mathrm{T} & \mathrm{NS}\end{array}$ & & & & \\
\hline
\end{tabular}

Table.5 Effect of $P$. deltoides trees spacing (S) and nutrient sources (T) on essential content (\%) in C. longa

\begin{tabular}{|c|c|c|c|c|}
\hline \multirow[t]{2}{*}{ NUTRIENT SOURCES } & \multicolumn{2}{|c|}{$\begin{array}{l}\text { P. deltoides tree } \\
\text { spacing }\end{array}$} & \multirow[b]{2}{*}{$\begin{array}{c}\mathrm{S}_{\mathbf{0}} \\
\text { (Open) }\end{array}$} & \multirow[b]{2}{*}{ Mean } \\
\hline & $\begin{array}{c}S_{1} \\
(6 \times 4 \mathrm{~m})\end{array}$ & $\begin{array}{c}S_{2} \\
(4 \times 4 \mathrm{~m})\end{array}$ & & \\
\hline $\mathbf{T}_{1}:$ Control & 3.14 & 3.10 & 2.45 & 2.90 \\
\hline $\mathrm{T}_{2}: 100 \%$ RDNF & 4.02 & 4.00 & 3.26 & 3.76 \\
\hline $\begin{array}{c}\mathrm{T}_{3}: 75 \% \text { RDNF }+25 \% \text { RDN through } \\
\text { FYM }\end{array}$ & 6.58 & 6.40 & 5.53 & 6.17 \\
\hline $\begin{array}{c}\mathrm{T}_{4}: 50 \% \text { RDNF }+50 \% \text { RDN through } \\
\text { FYM }\end{array}$ & 6.41 & 6.39 & 5.38 & 6.06 \\
\hline $\begin{array}{c}\mathrm{T}_{5}: 25 \% \text { RDNF }+75 \% \text { RDN through } \\
\text { FYM }\end{array}$ & 6.08 & 6.01 & 5.13 & 5.74 \\
\hline $\mathrm{T}_{6}: 100 \%$ RDN through FYM & 5.89 & 5.70 & 4.52 & 5.37 \\
\hline $\mathrm{T}_{7}: 100 \% \mathrm{RDN}$ through VC & 5.56 & 5.48 & 4.18 & 5.07 \\
\hline $\mathrm{T}_{8}:$ Jeevamrut (10 \%) & 4.38 & 4.25 & 3.73 & 4.12 \\
\hline Mean & 5.26 & 5.17 & 4.27 & \\
\hline $\begin{array}{ll}C D_{0.05} & \\
S & 0.15 \\
T & 0.25 \\
S \times T & \text { NS }\end{array}$ & & & & \\
\hline
\end{tabular}


Table.6 Effect of $P$. deltoides trees spacing $(\mathrm{S})$ and nutrient sources $(\mathrm{T})$ on crude fibre $(\%)$ in $C$. longa

\begin{tabular}{|c|c|c|c|c|}
\hline \multirow[t]{2}{*}{ NUTRIENT SOURCES } & \multicolumn{2}{|c|}{$\begin{array}{l}\text { P. deltoides tree } \\
\text { spacing }\end{array}$} & \multirow[b]{2}{*}{$\begin{array}{c}\mathbf{S}_{\mathbf{0}} \\
\text { (Open) }\end{array}$} & \multirow[b]{2}{*}{ Mean } \\
\hline & $\begin{array}{c}S_{1} \\
(6 \times 4 \mathrm{~m})\end{array}$ & $\begin{array}{c}\mathrm{S}_{2} \\
(4 \times 4 \mathrm{~m})\end{array}$ & & \\
\hline$T_{1}$ : Control & 3.05 & 2.96 & 3.45 & 3.15 \\
\hline $\mathrm{T}_{2}: 100 \% \mathrm{RDNF}$ & 3.44 & 3.18 & 4.64 & 3.75 \\
\hline $\begin{array}{c}\mathrm{T}_{3}: 75 \% \text { RDNF }+25 \% \text { RDN through } \\
\text { FYM }\end{array}$ & 5.93 & 5.77 & 6.03 & 5.91 \\
\hline $\begin{array}{c}\mathrm{T}_{4}: 50 \% \text { RDNF }+50 \% \text { RDN through } \\
\text { FYM }\end{array}$ & 5.72 & 5.38 & 5.88 & 5.66 \\
\hline $\begin{array}{c}\mathrm{T}_{5}: 25 \% \text { RDNF }+75 \% \text { RDN through } \\
\text { FYM }\end{array}$ & 5.40 & 5.11 & 5.61 & 5.37 \\
\hline$T_{6}: 100 \%$ RDN through FYM & 4.74 & 4.46 & 5.49 & 4.90 \\
\hline $\mathrm{T}_{7}: \mathbf{1 0 0} \% \mathrm{RDN}$ through VC & 4.25 & 3.97 & 5.23 & 4.48 \\
\hline$T_{8}:$ Jeevamrut (10 \%) & 3.38 & 3.19 & 4.59 & 3.72 \\
\hline Mean & 4.49 & 4.25 & 5.12 & \\
\hline $\begin{array}{ll}\mathrm{CD}_{0.05} & \\
\mathrm{~S} & \mathbf{0 . 2 4} \\
\mathrm{T} & \mathbf{0 . 3 8} \\
\mathrm{S} \times \mathrm{T} & \mathrm{NS}\end{array}$ & & & & \\
\hline
\end{tabular}

Fig.1 P. deltoides - C. longa agrisilviculture system

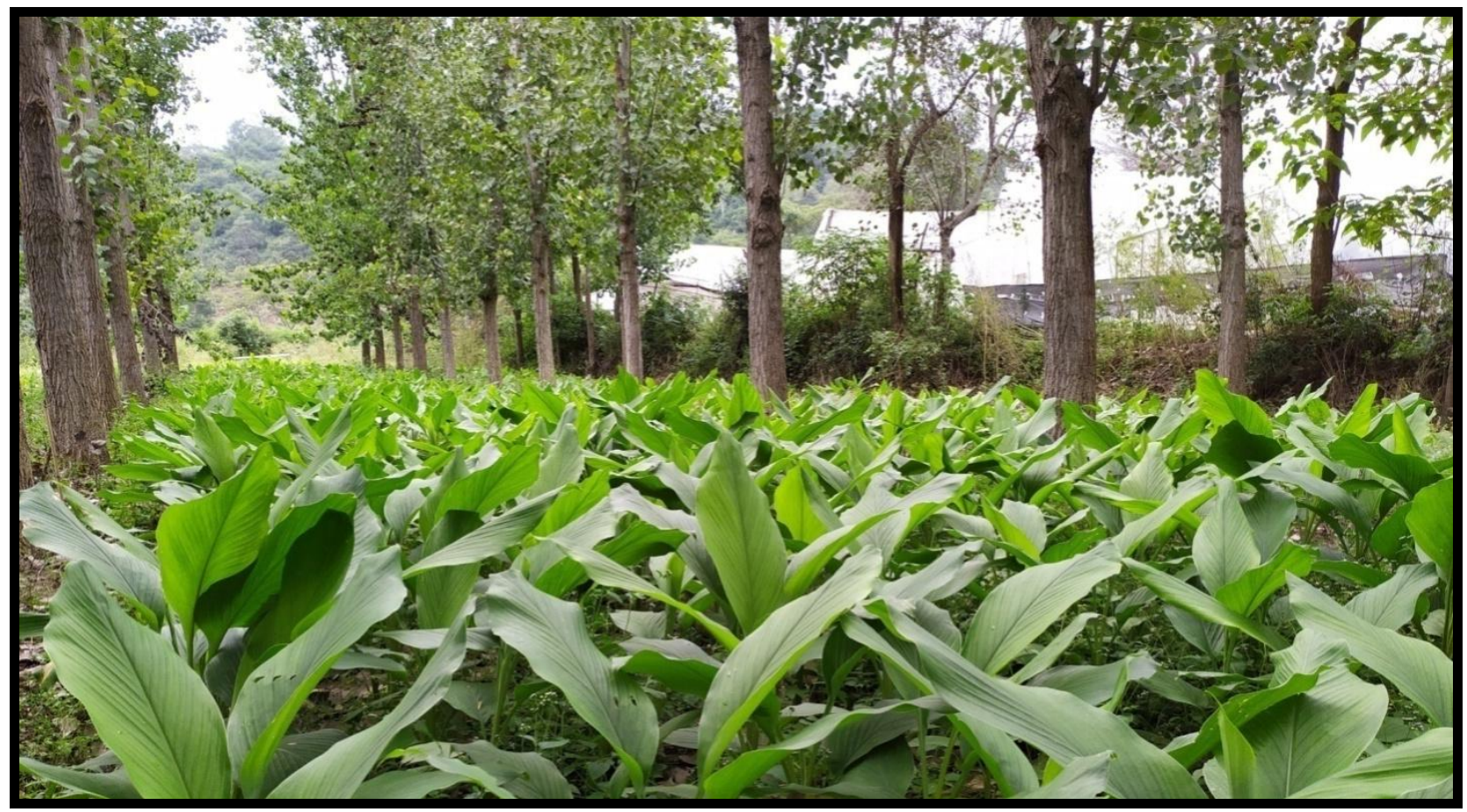


Fig.2 Curcumin extract in ethanol

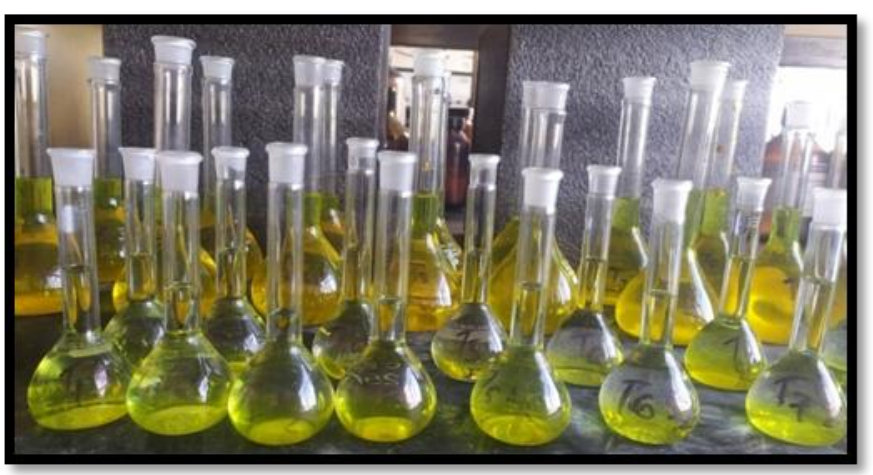

Fig.3 Absorbance of the curcumin extract using Spectro-20 D

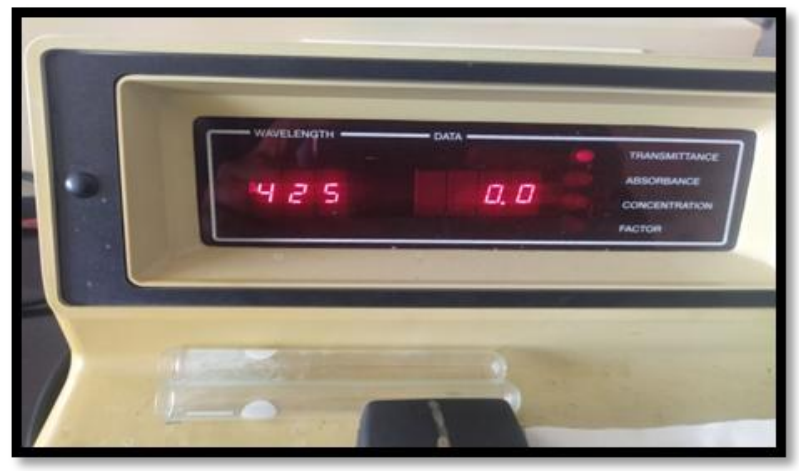

Fig.4 Estimation of oleoresin content in C. longa

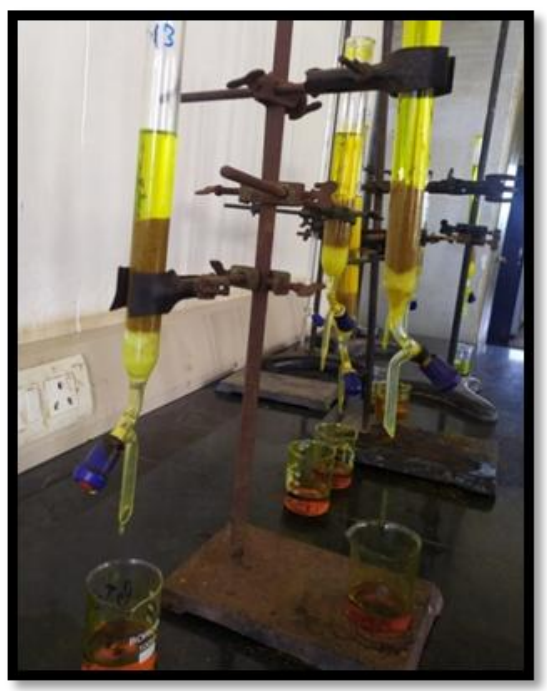


Fig.5 Clevenger's apparatus for extraction of essential oil

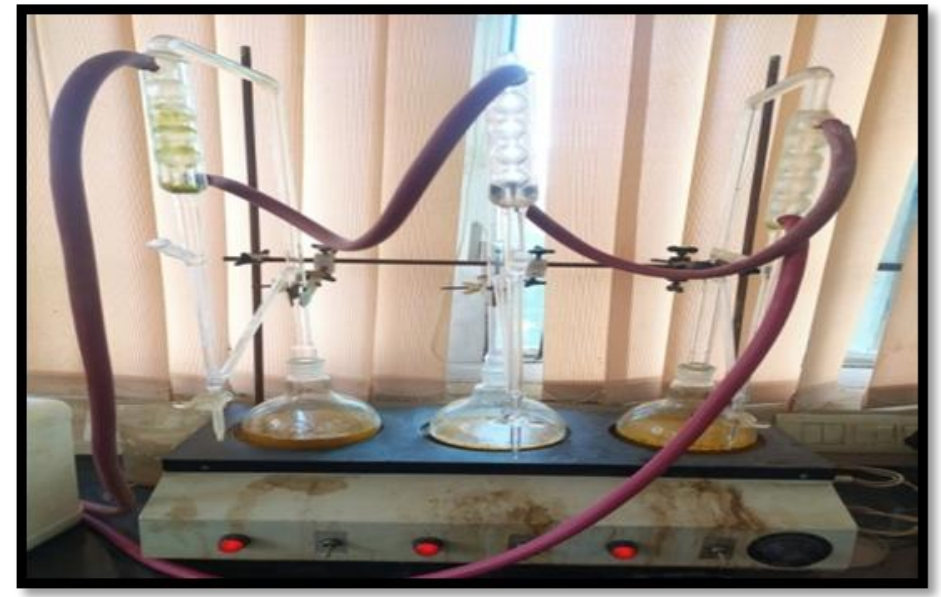

From the present study, it is concluded that in $P$. deltoides-C.longa agrisilviculture system espousal of treatment $\mathrm{T}_{3}(75 \% \mathrm{RDNF}+25 \%$ RDN through FYM) in wider spacing of Poplar trees is insinuated as a quality enhancing nutrient module.

\section{References}

Aarthi S, Suresh J and Prasath D. 2018. Variability and association analysis of curcumin content with yield components in turmeric. Electronic Journal of Plant Breeding 9:295-303.

Anonymous. 2014. Package of Practises for Vegetable Crops. Directorate of Extension Education, Dr YS Parmar University of Horticulture and Forestry, Nauni, Solan (HP) pp. 52-53.

Anonymous. 2017. Spices Board India, Calicut, Kerala.

ASTA. 1997. Official Analytical Methods. $4^{\text {th }}$ ed. American Spice Trade Association, Washington DC. 50p.

Chanchan M, Ghosh DK, Hore JK and Anitha M. 2017. Studies on response of manures and biofertilizers on growth and yield of turmeric (Curcuma longa L.). Journal of Crop and Weed 13:112-115.

Chandrasekhar G and Hore JK. 2019. Yield and quality of ginger as influenced by biofertilizers, organic and inorganic manures. International Journal of Current Microbiology and Applied Sciences 8:968-972.

Choudhry D. 2019. Study on the nutrient composition of local variety of turmeric (Curcuma longa). The Pharma Innovation Journal 8:205-207.

Hembram J. 2014. Production potential of turmeric under different cultural practices in guava based agrihorticulture practice of agroforestry. M.Sc. Thesis. Department of Forestry, Jawaharlal Nehru Krishi Vishwa Vidyalaya, Jabalpur (MP). 75p.

Hossain MA, Akamine H, Ishimine Y, Teruya R, Aniya Y and Yamawaki K. 2009. Effects of relative light intensity on the growth, yield and curcumin content of turmeric (Curcuma longa L.) in Okinawa, Japan. Plant Production Science 12:29-36.

Jaswal SC, Mishra VK and Verma KS. 1993. Intercropping ginger and turmeric with poplar (Populus deltoides 'G-3' Marsh). Agroforestry Systems 22:111-117.

Kittur BH, Sudhakara K, Kumar BM, Kunhamu TK, Sureshkumar P. 2015. Bamboo based agroforestry systems in Kerala, India: performance of turmeric (Curcuma longa L.) in the subcanopy of differentially spaced seven year-old 
bamboo stand. Agroforestry systems 90:237-250.

Kumar A, Tewari S, Rawat I, Pandey R, Kumar D and Anand R. 2018. Effect of nutrient sources on growth, yield and quality of turmeric under harad (Terminalia chebula) based agroforestry system. Indian Journal of Agroforestry 20:1-6.

Li S, Yuan W, Deng G, Wang P, Yang P and Aggarwal BB. 2011. Chemical composition and product quality control of turmeric (Curcuma longa L.). Pharmaceutical Crops 2:28-54.

Montemurro F. 2009. Different nitrogen fertilization sources, soil tillage, and crop rotations in winter wheat: effect on yield, quality, and nitrogen utilization. Journal of Plant Nutrition 32:1-18.

Padmapriya S, Chezhiyan N and Sathiyamurthy VN. 2007. Effect of shade and integrated nutrient management on biochemical constituents of turmeric (Curcuma longa L.) Journal of Horticultural sciences 2:123-129.

Padmapriya S. 2004. Studies on effect of shade, inorganic, organic and bio fertilizers on growth, yield and quality of turmeric (Curcuma longa L.) genotype CL 147. Ph.D. Thesis. Department of Spices and Plantation Crops, Horticultural College And Research Institute Tamil Nadu Agricultural University, Coimbatore. $285 \mathrm{p}$

Ranawat S, Pandey SBS, Singh J, Nayak D and Pushpanjali. 2018. Doubling the farmer's income through intercropping turmeric (Curcuma longa L.) under mandarin based agroforestry system in South- Eastern Rajasthan. Journal of Pharmacognosy and Phytochemistry 7:2560-2563.

Rao RM, Reddy RCK and Subbarayudu N. 1975. Promising turmeric types of Andhra Pradesh. Indian Spices 12:2-5.

Sarangi SK, Singh KA and Singh R.2007. Performance of Turmeric (Curcuma longa) under shade of tree species. Range Management and Agroforestry 28:44-46.

Shah HA and Muthuswamy S. 1981. Studies on the influence of $\mathrm{N}$ on the yield and yield components of turmeric. Indian Cocoa, Arecanut and Spices Journal 5:9-10.

Suvera AKH, Thakur NS and Jha SK. 2015. Herbage and essential oil yield of Ocimum spp. intercropped under Pongamia pinnata based silvimedicinal systems in Gujarat, India. The Bioscan 10:81-85.

Thakur NS, Verma KS and Rana RC. 2009. Effect of tree-crop combinations and nitrogen levels on fresh herbage and oil yield of sacred basil (Ocimum sanctum) grown in agrihorti-silvi-pasture system in mid hill Himalayas. Indian Perfumer 53:39-44.

Verma P, Singh R and Parmar AS. 2012. Influence of integrated nutrient management on yield and curcumin content of turmeric. A Journal of Multidisciplinary Advance Research $1: 33-38$

\section{How to cite this article:}

Umakanta Dash, Bhupender Gupta, Jyotiraditya Das and Shilpa. 2021. Quality Attributes of Curcuma longa in response to Populus deltoides Tree Spacings and Nutrient Sources. Int.J.Curr.Microbiol.App.Sci. 10(02): 1589-1598. doi: https://doi.org/10.20546/ijcmas.2021.1002.189 